\title{
Labyrinthe
}

1 | 1998

Numéro 1

\section{Horace Vernet, peintre de tableaux bibliques}

\section{Annie Cartoux}

\section{OpenEdition}

\section{Journals}

Electronic version

URL: http://journals.openedition.org/labyrinthe/334

DOI: $10.4000 /$ labyrinthe.334

ISSN: 1950-6031

\section{Publisher}

Hermann

Printed version

Date of publication: 15 October 1998

Number of pages: $45-62$

\section{Electronic reference}

Annie Cartoux, « Horace Vernet, peintre de tableaux bibliques », Labyrinthe [Online], 1 | 1998, Online since 04 March 2005, connection on 01 May 2019. URL : http://journals.openedition.org/ labyrinthe/334 ; DOI : 10.4000/labyrinthe.334

This text was automatically generated on 1 May 2019.

Propriété intellectuelle 
Horace Vernet, peintre de tableaux bibliques

Annie Cartoux 